DOI: https://doi.org/10.24127/ajpm.v10i3.3705

\title{
STUDI META-ANALISIS: EFEKTIVITAS MODEL PROJECT-BASED LEARNING TERHADAP KEMAMPUAN BERPIKIR KREATIF MATEMATIS SISWA
}

\author{
Yunita ${ }^{1}$, Dadang Juandi ${ }^{2}$, Aan Hasanah ${ }^{3,}$ Maximus Tamur ${ }^{4 *}$ \\ ${ }^{1,2,3}$ Universitas Pendidikan Indonesia, Bandung, Indonesia \\ ${ }^{4 *}$ Universitas Katolik Indonesia Santu Paulus, Ruteng, Indonesia \\ * Corresponding author. Universitas Katolik Indonesia Santu Paulus, Ruteng, Indonesia \\ E-mail: $\quad \frac{\text { yunita1996nita@upi.edu }}{\text { d) }}$ \\ aanhasanah@upi.ed ${ }^{3)}$ \\ maximustamur@unikastpaulus.ac.id ${ }^{4 *)}$
}

Received 01 May 2021; Received in revised from 08 September 2021; Accepted 22 September 2021

\begin{abstract}
Abstrak
Studi individu tentang efektivitas model project-based learning (PjBL) telah banyak dilakukan dengan hasil yang beragam. Namun sejauhmana karakteristik penelitian berperan dalam variasi hasil studi individu, belum diekplorasi. Sebagai upaya mengisi kekosongan tersebut maka penelitian meta-analysis ini dilakukan untuk menentukan efek keseluruhan model PjBL pada kemampuan berpikir kreatif matematis, dan dilakukan mempertimbangkan peran moderator dalam mengimplemtasikannya lebih lanjut. Pencarian studi dilakukan pada rentang tahun 2014 hingga 2020 pada basis data ERIC, Google Schoolar dan IOP Publishing. Hasil pencarian memberikan dua belas studi yang memenuhi syarat inklusi untuk diekstraksi. Perhitungan menggunakan bantuan software CMA versi. 3.3, dan menggunakan model efek-acak sebagai metode estimasi. Sebagai hasil penelitian, diperoleh ukuran efek keseluruhan studi adalah 1,190 yang menunjukkan bahwa implementasi PjBL berdampak besar terhadap kemampuan berpikir kreatif matematis siswa. Selain itu, hasil analisis moderator berimplikasi pada implementasi PjBL dimasa depan. Keterbatasan penelitian dibahas sebagai ide dasar untuk penelitian selanjutnya.
\end{abstract}

Kata kunci: Berpikir kreatif; meta-analisis; pembelajaran berbasis proyek; pendidikan matematika.

\begin{abstract}
Many individual studies on the effectiveness of the project-based learning (PjBL) model have been carried out with mixed results. However, the extent to which research characteristics play a role in the variation in individual study outcomes has not been explored. As an effort to fill this gap, this metaanalysis study was conducted to determine the overall effect of the PjBL model on mathematical creative thinking skills, and to consider the role of the moderator in further implementing it. Search for studies from 2014 to 2020 on the ERIC, Google Schoolar and IOP Publishing databases. The search results provided twelve studies that met the requirements for extraction. Calculations using the help of the CMA version of the software. 3.3, and use a random-effect model as the estimation method. As a result of the study, the overall effect size of the study was 1.190, indicating that the implementation of PjBL had a major impact on students' mathematical creative thinking abilities. In addition, the results of the moderator analysis have implications for the implementation of PjBL in the future. The limitations of the study are discussed as a basic idea for further research.
\end{abstract}

Keywords: Creative thinking; mathematics education; meta-analysis; project-based learning; 
DOI: https://doi.org/10.24127/ajpm.v10i3.3705

\section{PENDAHULUAN}

Kurikulum pendidikan di Indonesia seperti kurikulum 2013 revisi dan kegiatan Asesmen Kompetensi Minimum mewajibkan seluruh civitas sekolah menciptakan suatu proses pembelajaran yang sesuai dengan karakteristik siswa. Berbagai karakteristik siswa yang ditunjukan melalui kegiatan fisik dan mental sangat perlu difasilitasi untuk melakukan latihan keterampilan berpikir tingkat tinggi (HOTS) (Hidayah et al., 2020). Dalam kemampuan berpikir tingkat tinggi melibatkan berbagai kemampuan, salah satunya kemampuan berpikir kreatif matematis (Yunita et al., 2018). Kemampuan berpikir kreatif, kecerdasan, mentalitas dan sosial yang dominan mampu membentuk siswa menjadi berbakat (Ngiamsunthorn, 2020). Apabila siswa memiliki kemampuan berpikir kreatif, maka ia akan menghasilkan ide yang bervariasi dan dari ide-ide tersebut ia pun mampu memilih jawaban yang paling tepat dalam memecahkan suatu masalah (Syahrin et al., 2019). Pada pembelajaran matematika, aspek kreatif dalam otak mampu membantu menjelaskan konsep-konsep abstrak sehingga menimbulkan penguasaan siswa menjadi lebih besar dan luas (Damayanti \& Sumardi, 2018). Jadi kemampuan berpikir kreatif matematis memiliki dampak yang sangat positif dalam kemajuan perkembangan siswa dibidang matematika.

Untuk mengembangkan kemampuan berpikir kreatif matematis siswa dibutuhkan model pembelajaran yang aktif dan berpusat pada siswa. Model project-based learning ( $\mathrm{PjBL})$ merupakan suatu model pembelajaran yang melibatkan siswa secara penuh dalam merencanakan dan menyelesaikan suatu proyek, hal ini pun akan meningkatkan hard skill dan soft skill siswa (Jalinus et al., 2020). Melalui PjBL, kemampuan berpikir kreatif dapat diamati dengan jelas dari produk yang dihasilkan pada pembelajaran matematika sekolah (Ummah et al., 2019). Model PjBL mampu memberikan motivasi siswa dan sifat gigih pada proses pembelajaran tingkat tinggi melalui sajian proyek yang dibentuk dari kumpulan tugas yang kompleks (Girgin, 2020). Jadi model PjBL merupakan suatu model yang bisa dijadikan sebagai pilihan untuk diterapkan dalam meningkatkan kemampuan berpikir kreatif matematis siswa.

Seiring berjalannya waktu, telah banyak dilakukan penelitian eksperimen mengenai model PjBL terhadap kemampuan berpikir kreatif matematis. Beberapa studi menampilkan hasil penelitiannya meliputi adanya pengaruh positif secara signifikan pada penerapan model PjBL terhadap kemampuan berpikir kreatif matematis siswa daripada menggunakan model pembelajaran konvensional (Octariani \& Rambe, 2020); Noviyana, 2017; Nurhayati, 2017). Sedangkan beberapa studi lainnya menujukan hasil penelitian yang berbeda yaitu bahwa penerapan model PjBL tidak memberikan pengaruh positif secara signifikan terhadap kemampuan berpikir kreatif matematis siswa daripada menggunakan model pembelajaran konvensional (Sudianto et al., 2019; Shalihah et al., 2020). Hal ini menunjukkan tidak adanya konsistensi pada hasil penelitian dengan topik yang sama. Padahal para guru matematika ingin memperoleh informasi yang akurat dan saling mendukung untuk dipertimbangkan dalam menerapkan model PjBL secara efektif terhadap peningkatan kemampuan berpikir kreatif matematis. 
Adapun cara menganalisis dan mensintesis secara kuantitatif dari beberapa studi yang dikumpulkan baik dari konferensi, artikel jurnal, skripsi, disertasi dan tesis untuk menyediakan informasi penting bagi para pendidik butuhkan dan pembuat kebijakan (OhYoung et al., 2020; Moeyaert, 2019; Tamur \& Juandi, 2020; Tamur, Juandi, \& Kusumah, 2020). Studi meta-analisis merupakan suatu cara yang paling utama dalam menggabungkan beberapa penelitian, memperkuat tingkat validitas hasil penelitian yang ada dengan temuan serupa dan mampu menjelaskan perbedaan tersebut jika terdapat perbedaan hasil (Kot et al., 2018; Siegel et al., 2021; Juandi et al., 2021; Suparman, Juandi, et al., 2021). Metaanalisis dilakukan untuk meringkas bukti populasi untk kemudian mempertimbangkan implikasinya (Lee, 2019; Tamur, Jehadus et al., 2020; Tamur, Kusuham, Juandi et al., 2021).

Berdasarkan masalah yang telah dijelaskan, terlihat bahwa perlu dilakukan meta-analitis terhadap efektivitas PjBL terhadap kemampuan berpikir kreatif matematis siswa. Meskipun sebelumnya Balemen, N., \& Ozer Keskin (2018), dan Anggreni et al. (2019) telah melakukan meta-analisis pada implementasi model PjBL, namum subyek yang diteliti adalah bidang sains. Hingga saat ini belum terdapat penelitian mengenai studi meta-analisis tersebut terhadap kemampuan berpikir kreatif matematis siswa.

Oleh karena itu penelitian ini bertujuan untuk menganalisis, mengevaluasi dan meneliti besarnya ukuran efek pada implementasi efektivitas model PjBL terhadap kemampuan berpikir kreatif matematis siswa. Selain itu, meninjau besarnya ukuran efek yang bervariasi pada karakteristik studi meliputi substantive (jenjang pendidikan, teknik pengambilan sampel dan ukuran sampel) dan ekstrinsik (tahun publikasi dan tipe publikasi).

\section{METODE PENELITIAN}

Penelitian ini menggunakan metode studi meta-analisis. Adapun tahapan-tahapan penelitian ini meliputi penentuan kriteria inklusi, tahap pencarian studi, tahap kualitas studi, tahap ekstraksi data, dan terakhir tahap analisis statistik (Fadhli et al., 2020).

Tahap penentuan kriteria inklusi guna mempermudah pencarian studi pada tahap berikutnya. Kriterian inklusi penelitian ini meliputi :

1. Tahun publikasi studi pada rentang 1 Januri 2014 hingga 31 Desember 2020;

2. Studi menggunakan metode penelitian eksperimen atau quasi eksperimen;

3. Minimal 1 kelompok eksperimen dengan model PjBL dan kelompok pembadingnya sebagai kelompok kontrol dengan model konvensional;

4. Studi memuat kelompok statistic yaitu nilai mean, simpangan baku dan ukuran sampel; ukuran sampel dan nilai t-value; atau ukuran sampel dan p-value.

Tahap pencarian studi menggunakan alat pencarian berupa ERIC (Education Resources Information Center), Google Scholar dan IOP Publishing. Adapun kata kunci yang digunakan bagi studi yang berbahasa Indonesia "Pembelajaran berbasis proyek", "Kemampuan berpikir kreatif matematis". Studi yang menggunakan Bahasa Inggris menggunakan kata kunci "Projectbased learning" dan " creative mathematical ability". Dari hasil pencarian studi berdasarkan kriteria 
DOI: https://doi.org/10.24127/ajpm.v10i3.3705

inklusi diperoleh 12 studi yang relevan dari 35 studi yang terkumpul

Pada tahap selanjutnya, tahap melihat kualitas studi yang dilakukan oleh dua pengkoding terpilih berdasarkan keahlian dalam bidang penelitian meta-analisis. Dua pengkoding akan melakukan pengkodingan pada miscrosoft excel lalu menilai studi terkumpul pada lembar persetujuan. Lembar persetujuan dari para pengkoding dihitung menggunakan perhitungan Cohen's kappa (De Raadt et al., 2019) melalui bantuan software SPSS.

Setelah melalui tahap kualitas studi, diperoleh 12 studi yang relevan. Berikut daftar data studi yang akan dianalisis menggunakan metode metaanalisis ditunjukan pada Tabel 1 .

Tabel 1. Daftar studi yang akan dianalisis

\begin{tabular}{ccl}
\hline No & Kode Studi & \multicolumn{1}{c}{ URL } \\
\hline 1 & S06 & https://ejournal.stkipbbm.ac.id/index.php/gm/issue/archive \\
2 & S09 & http://ejournal.stkipmpringsewu-lpg.ac.id/index.php/edumath \\
3 & S15 & http://eprints.ums.ac.id/33187/ \\
4 & S16 & http://dx.doi.org/10.20414/betajtm.v10i2.104 \\
5 & S18 & http://simki.unpkediri.ac.id/detail/13.1.01.05.0099 \\
6 & S20 & http://repository.radenintan.ac.id/7520/ \\
7 & S21 & http://journal.unnes.ac.id/sju/index.php/ujmer \\
8 & S22 & http://dx.doi.org/10.1088/1742-6596/1563/1/012044 \\
9 & S24 & http://jurnal.uinsu.ac.id/index.php/axiom/index \\
10 & S26 & https://journal.uniku.ac.id/index.php/JESMath/article/view/281 \\
11 & S29 & http://repository.uinjkt.ac.id/dspace/handle/123456789/40348 \\
12 & S35 & http://repovos.int-upi.edu/36248/ \\
\hline
\end{tabular}

Selain itu, adapun jumlah karakteristik yang diperoleh dari dua belas studi pada Tabel 2. Karakteristik studi nomor urut 1 hingga 3 disebut subtantif dan karakteristik studi nomor urut 4 dan 5 disebut ektrinsik.

Tabel 2. Jumlah karakteristik studi yang diperoleh.

\begin{tabular}{lllc}
\hline No & \multicolumn{1}{c}{ Karakteristik Studi } & \multicolumn{1}{c}{ Kelompok } & Jumlah \\
\hline 1 & Jenjang Pendidikan & Sekolah Dasar & 1 \\
& & Sekolah Menengah Pertama & 6 \\
& & Sekolah MenangahAtas & 4 \\
\multirow{2}{*}{2.} & \multirow{2}{*}{ Teknik Pengambilan Sampel } & Perguruan Tinggi & 1 \\
& & Purposive & 3 \\
3 & Ukuran Sampel & Random & 9 \\
& & $\leq 30$ & 2 \\
4 & Tahun Publikasi & $>30$ & 10 \\
& & 2014 & 1 \\
& & 2015 & 1 \\
& & 2016 & 2 \\
& & 2017 & 4 \\
& & 2019 & 2 \\
5 & Tipe Publikasi & 2020 & 2 \\
& & Proceeding & 7 \\
& & Jurnal & 3 \\
\hline
\end{tabular}


Setelah data diekstraksi, tahap selanjutnya analisis statistik. Dua belas studi dianalisis menggunakan bantuan software Comprehensive Meta-analysis (CMA) versi 3.3 untuk memperoleh ukuran efek. Analisis statistik dimulai dengan menghitung semua ukuran efek tiap studi dan ukuran efek rata-ratanya (true effect sizes), kemudian menentukan metode estimasi, selanjutnya menentukan bias publikasi, dan terakhir menganalisis karakteristik studi.

Tabel 3. Kategori kelompok ukuran efek menggunakan interpretasi Cohen

\begin{tabular}{ccc}
\hline No & ES & Interpretasi \\
\hline 1 & $0,00-0,19$ & Diabaikan \\
2 & $0,20-0,49$ & Kecil \\
3 & $0,50-0,79$ & Sedang \\
4 & $0,79-1,29$ & Besar \\
5 & $1,30-$ keatas & Sangat Besar \\
\hline
\end{tabular}

(Cohen et al., 2018).

Ada atau tidaknya variasi dalam kumpulan ukuran efek meta-analisis dapat dilihat dari q-value atau p-value dengan nilai signifikan $0,05 \%$ (Maeda \& Harwell, 2016). Ada dua model ukuran efek. Studi dikatakan homogen apabila $p>0,05$ maka model estimasi menggunakan model efek tetap sedangkan $\mathrm{p}<0,05$ dikatakan ukuran efek antar studi bervariasi maka dipilih metode estimasi yakni model ukuran efek acak (Paloloang et al., 2020). Studi yang memuat statistik yang dibutuhkan dalam meta-analisis diperlukan uji bias publikasi (Juandi \& Tamur, 2020; Sari et al., 2021; Susanti et al., 2020; Suparman, Juandi, et al., 2021a; Tamur, Juandi, \& Adem, 2020; Yunita et al., 2020). Untuk menguji ada atau tidaknya bias publikasi, menggunakan funnel plot untuk menentukan simetris, trim and fill untuk mengevaluasi funnel plot dalam bentuk ada atau tidaknya jumlah studi yang harus dikeluarkan, dan terakhir fail-safe $N$ (FSN) dengan cara memperhitungkan jumlah studi yang diperlukan untuk membatalkan efek keseluruhan (Fournier et al., 2010).

\section{HASIL DAN PEMBAHASAN}

Dua belas studi dilakukan penilaian kualitas oleh dua pengkoding menggunakan microsoft excel dan juga memberikan penilaian mengenai persetujuan terhadap dua belas studi. Penilaian persetujuan dari dua pengkoding sebesar 0,75. Hal ini menunjukkan bahwa tingkat persetujuan antar pengkode dalam mengekstrak informasi dari studi primer kedalam lembar pengkodean hampir sempurna. Dengan demikian hasil penelitian dapat diandalkan.

Adapun hasil ukuran efek dari dua belas studi disajikan pada Tabel 4 .

Tabel 4. Daftar ukuran efek dua belas studi

\begin{tabular}{ccccc}
\hline No & Kode & $\begin{array}{c}\text { Ukuran } \\
\text { Efek }\end{array}$ & $\begin{array}{c}\text { Standard } \\
\text { Error }\end{array}$ & $\mathbf{9 5 \%}$ CI \\
\hline 1 & S06 & 3,071 & 0,370 & {$[2,346 ; 3,796]$} \\
2 & S09 & 3,608 & 0,413 & {$[2,798 ; 4,418]$} \\
3 & S15 & 0,671 & 0,248 & {$[0,184 ; 1,158]$} \\
4 & S16 & 1,065 & 0,273 & {$[0,530 ; 1,600]$} \\
5 & S18 & 1,535 & 0,282 & {$[0,983 ; 2,087]$} \\
6 & S20 & 0,748 & 0,245 & {$[0,268 ; 1,227]$} \\
7 & S21 & 0,085 & 0,245 & {$[-0,395 ; 0,566]$} \\
8 & S22 & 0,159 & 0,314 & {$[-0,457 ; 0,775]$} \\
9 & S24 & 0,752 & 0,248 & {$[0,265 ; 1,239]$} \\
10 & S26 & 0,938 & 0,261 & {$[0,428 ; 1,449]$} \\
11 & S29 & 1,166 & 0,266 & {$[0,645 ; 1,686]$} \\
12 & S35 & 0,963 & 0,247 & {$[0,479 ; 1,446]$} \\
\hline
\end{tabular}

Terdapat tiga studi yang memiliki ukuran efek dengan kategori sangat besar meliputi 3,071; 3,608; dan 1,535. Selain itu terdapat empat studi yang memiliki ukuran efek dengan kategori besar yaitu 1,$065 ; 0,938 ; 1,166$; dan 0,963. Adapun tiga studi yang memiliki ukuran efek sedang yaitu ,671; 0,748; dan 0,752. Lalu ada dua studi 
yang memiliki ukuran efek yang terabaikan yaitu 0,085 dan 0,159 . Nilai rata-rata ukuran efek dari dua belas studi adalah sebesar 1,230 tergolong pada kategori besar. Adapun pengaruh intervensi pembelajaran terhadap kemampuan matematis sebesar 0,155 (Kadir, 2017).

Selanjutnya meneliti bias publikasi pada dua belas studi. Gambar plot corong dari ukuran efek dua belas studi disajikan pada Gambar. 1

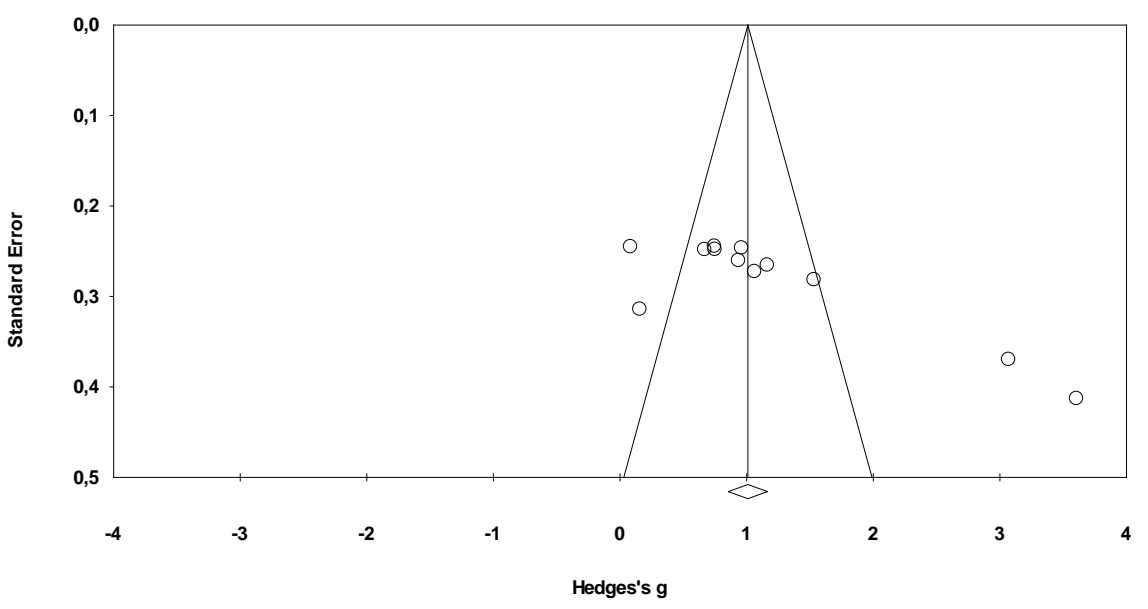

Gambar 1. Plot corong ukuran efek

Gambar 1 menunjukkan bahwa kumpulan ukuran efek tidak sepenuhnya berdistribusi simetris. Akibatnya ada potensi bahwa ukuran efek studi penelitian ini mungkin tidak merepresentasikan true effect size (Borenstein et al., 2009). Untuk meneliti apakah ada indikasi bias publikasi pada penelitian ini maka uji trim and fill dan FSN diterapkan (Borenstein et al., 2009). Prosedur ini membantu peneliti untuk mengeluarkan studi yang terindikasi bias. Hasil uji trim and fill disajikan pada Tabel 4.

Tabel 5. Hasil uji Trim dan Fill

\begin{tabular}{clccc}
\hline No & & $\begin{array}{c}\text { Studis } \\
\text { Trim }\end{array}$ & $\begin{array}{c}\text { Fixed } \\
\text { effect }\end{array}$ & $\begin{array}{c}\text { Random } \\
\text { effect }\end{array}$ \\
\hline 1 & $\begin{array}{l}\text { Observed } \\
\text { values }\end{array}$ & & 1,009 & 1,190 \\
2 & $\begin{array}{l}\text { Adjusted } \\
\text { values }\end{array}$ & 0 & 1,009 & 1,190 \\
\hline
\end{tabular}

Ketika Tabel 5 diberiksa tampak
bahwa hasil observasi (Observed values) dan hasil yang dibuat berdasarkan efek virtual (Adjusted values) memberikan nilai yang sama.
Tampak juga bahwa banyaknya studi yang dikelurkan adalah nol. Hal ini menunjukkan bahwa penelitian ini tidak terindikasi bias publikasi. Tidak ada studi yang dikeluarkan dari analisis karena indikasi bias publikasi.

Selanjutnya untuk menilai apakah ukuran efek keseluruhan studi tidak sensitif terhadap perubahan maka uji FSN diterapkan. Jika nilai FSN / (5k $+10)>1$ dengan $\mathrm{k}$ adalah jumlah studi yang dimasukkan dalam meta-analisis maka penelitian ini tahan terhadap bias publikasi (Mullen et al., 2001). Dari hasil perhitungan menggunakan aplikasi CMA versi 3.3, diperoleh nilai $\mathrm{N}$ adalah 586 dengan dua belas studi yang dianalisis. Kemudian nilai tersebut disubstitukan kedalam rumus

$$
\frac{N}{(5 k+10)}=\frac{585}{(5(12)+10)}=\frac{586}{(60+10)}=8,371 .
$$

Nilai 8,371 lebih besar dari 1, sehingga dapat diartikan bahwa dua belas studi yang dianalisis ini bebas dari publikasi 
dan tidak sensitif terhadap perubahan (Juandi, Kusumah, Tamur, Perbowo, \& Wijaya, 2021; Suparman, Tamur, et al., 2021; Suparman, Juandi, et al., 2021a).
Selanjutnya menentukan model ukuran efek berdasarkan uji heterogenitas. Pada Tabel 6 disajikan dua model ukuran efek.

Tabel 6. Rekapitulasi ukuran efek berdasarkan model

\begin{tabular}{ccccccccc}
\hline \multirow{2}{*}{ No } & \multirow{2}{*}{ Model } & Jumlah & Ukuran & \multicolumn{3}{c}{ Heterogenitas } & \multicolumn{2}{c}{ Test of null (2-Tail) } \\
\cline { 6 - 9 } & & Studi & Efek & Q & df & P & Z & P \\
\hline $\mathbf{1}$ & Fixed effect & 12 & 1,010 & 100,226 & 11 & 0,000 & 12,790 & 0,00 \\
$\mathbf{2}$ & Random effect & 12 & 1,190 & & & & 4,953 & 0,00 \\
\hline
\end{tabular}

Ketika Tabel 6 diperiksa tampak bahwa nilai Q adalah 100,226. Nilai ini ditemukan lebih besar dari nilai Q tabel yaitu 19,675 dengan derajat kebabasan 11 paad Tabel $\chi^{2}$ dan $\mathrm{p}<0,05$. Hal ini menunjukkan bahwa dua belas studi bervariasi maka model estimasi yang digunakan adalah model efek acak dengan ukuran efek sebesar 1,190. Apabila dipilih model ukuran efek acak, maka ada indikasi bahwa kekuatan studi individu lebih rendah daripada penelitian yang dilakukan secara studi meta-analisis selain itu adanya kebutuhan penelitian lanjutan berupa analisis variabel moderator (Jackson \& Turner, 2017; Juandi \& Tamur, 2021;
Tamur et al., 2021; Tamur, Ndiung, et al., 2021). Nilai $Z$ yang disajikan adalah 4,953 dan $\mathrm{p}<005$, maka dapat disimpulkan bahwa terdapat perbedaan yang signifikan penerapan model PjBL terhadap kemampuan berpikir kreatif matematis siswa daripada penerapan model konvensional dengan memiliki ukuran efek besar sekitar 1,190 dan tingkat kepercayaan $95 \%$.

Selanjutnya analisis karakteristik studi pada masing-masing kelompok aspek yang dianalisis. Ada dua aspek yang dianalisis yaitu aspek subtantif dan ektrinsik. Pada Tabel 7 disajikan analisis karakteristik studi beradasarkan aspek subtantif.

Tabel 7. Analisis subtantif pada karakteristik studi

\begin{tabular}{|c|c|c|c|c|c|c|c|c|c|}
\hline \multirow[t]{2}{*}{ No } & \multirow{2}{*}{$\begin{array}{c}\text { Karakterstik } \\
\text { Studi }\end{array}$} & \multirow[t]{2}{*}{ Grup } & \multirow[t]{2}{*}{$\mathbf{N}$} & \multirow{2}{*}{$\begin{array}{c}\text { Hedge's } \\
\text { g }\end{array}$} & \multicolumn{2}{|c|}{$\begin{array}{c}\text { Test of Null } \\
\text { (2-Tail) }\end{array}$} & \multicolumn{3}{|c|}{ Heterogenitas } \\
\hline & & & & & $\mathbf{Z}$ & $\mathbf{P}$ & Qb & Df (Q) & p \\
\hline \multirow[t]{4}{*}{1} & & Sekolah Dasar & 1 & 0,159 & 0,505 & 0,614 & \multirow{4}{*}{8,572} & \multirow{4}{*}{3} & \multirow{4}{*}{0,036} \\
\hline & Jenjang & Sekolah Menegah Pertama & 6 & 1,449 & 4,434 & 0,000 & & & \\
\hline & \multirow{2}{*}{ Pendidikan } & Sekolah Menengah Atas & 4 & 1,133 & 2,143 & 0,032 & & & \\
\hline & & Perguruan Tinggi & 1 & 0,938 & 3,601 & 0,000 & & & \\
\hline \multirow[t]{2}{*}{2} & Ukuran & $\leq 30$ & 2 & 0,625 & 1,381 & 0,167 & \multirow{2}{*}{1,654} & & \multirow{2}{*}{0,019} \\
\hline & Sampel & $\geq 31$ & 10 & 1,308 & 4,730 & 0,000 & & & \\
\hline \multirow[t]{2}{*}{3} & Pengambilan & Purposive & 3 & 0,883 & 6,078 & 0,000 & \multirow{2}{*}{1,377} & & \multirow{2}{*}{0,024} \\
\hline & Sampel & Random & 9 & 1,310 & 3,926 & 0,000 & & & \\
\hline
\end{tabular}

Pertama, pada Tabel 7. karakteristik studi berdasarkan jenjang pendidikan diperoleh ukuran efek pada jenjang Sekolah Dasar sebesar 0,159 (diabaikan), Sekolah Menengah Pertama sebesar 1,449 (sangat besar), Sekolah Menengah Atas sebesar 1,133 (besar), dan Perguruan Tinggi sebesar 0,938 (besar). Model PjBL memliki efek besar apabila diterapkan pada jenjang sekolah Menengah Pertama. Berdasarkan nilai $\mathrm{Qb}=8,572>\mathrm{Q}$ tabel $=$ 7,814 dan $p<0,05$, dapat diartikan bahwa implementasi model PjBL 
berbeda secara signifikan terhadap kemampuan berpikir kreatif matematis siswa daripada model konvensional. Berbeda pada bidang sains bahwa model PjBL lebih efektif diterapkan pada jenjang pendidikan Sekolah Menengah Atas (Anggreni et al., 2019).

Kedua, informasi yang diperoleh dari Tabel 6 mengenai karakteristik studi berdasarkan ukuran sampel bahwa nilai $\mathrm{Qb}=1,654<\mathrm{Q}$ tabel $=3$ 3,841dan $\mathrm{p}>0,05$. Hal ini berarti terdapat perbedaan ukuran efek studi berdasakan ukuran sampel. Dengan perkataan lain perbedaan ukuran sampel memoderasi variasi ukuran efek studi. Dari kategori ukuran sampel sangat jelas bahwa penerapan model PjBL lebih efektif apabila ukuran sampel tidak kurang dari 31 siswa. Hal ini tidak sejalan dengan penelitian yang dilakukan oleh ( Tamur \& Juandi, 2020) pada model pembelajaran berbasis kontruktivis lebih efektif diterapkan pada ukuran sampel kurang dari 30 siswa.
Ketiga, berdasarkan karakteristik teknik pengambilan sampel bahwa teknik pengambilan sampel secara purposive memiliki ukuran lebih kecil daripada menggunakan teknik pengambilan secara random. Oleh karena itu, teknik pengambilan secara random lebih cocok pada penelitian model PjBL. Hal ini pun sejalan pada penelitian penerapan model pembelajaran kontruktivis lebih efektif apabila teknik pengambilan sampel dilakukan dengan system random (Arik \& Yilmaz, 2020). Berdasarkan Tabel 6 bahwa $\mathrm{Qb}=1,377<\mathrm{Qtabel}=3,841$ dan $\mathrm{p}>0,05$, dapat disimpulkan bahwa karakteristik studi yang ditinjau dari teknik pengambil sampel menunjukkan tidak terdapat perbedaan secara signifikan pengaruh model $\mathrm{PjBL}$ terhadap kemampuan berpikir kreatif matematis siswa.

Selanjutnya analisis karakteristik studi pada aspek ektrinsik ditampilkan pada Tabel 8.

Tabel 8. Analisis ekstrinsik pada karakteristik studi

\begin{tabular}{|c|c|c|c|c|c|c|c|c|c|}
\hline \multirow[t]{2}{*}{ No } & \multirow{2}{*}{$\begin{array}{l}\text { Karaktersitik } \\
\text { Studi }\end{array}$} & \multirow{2}{*}{ Grup } & \multirow{2}{*}{$\mathbf{N}$} & \multirow{2}{*}{$\begin{array}{c}\text { Hedge's } \\
\mathrm{g}\end{array}$} & \multicolumn{2}{|c|}{$\begin{array}{l}\text { Test of Null (2- } \\
\text { Tail) }\end{array}$} & \multicolumn{3}{|c|}{ Heterogenitas } \\
\hline & & & & & $\mathbf{Z}$ & $\mathbf{P}$ & $\mathbf{Q}$ & Df $(\mathbf{Q})$ & $\mathbf{p}$ \\
\hline \multirow[t]{6}{*}{1} & Tahun & 2014 & 1 & 1,166 & 4,389 & 0,000 & \multirow{6}{*}{6,663} & \multirow{6}{*}{5} & \multirow{6}{*}{0,470} \\
\hline & Publikasi & 2015 & 1 & 0,671 & 2,701 & 0,007 & & & \\
\hline & & 2016 & 2 & 0,951 & 5,310 & 0,000 & & & \\
\hline & & 2017 & 4 & 1,697 & 3,277 & 0,001 & & & \\
\hline & & 2019 & 2 & 0,417 & 1,258 & 0,208 & & & \\
\hline & & 2020 & 2 & 1,609 & 1,105 & 0,269 & & & \\
\hline \multirow[t]{4}{*}{2} & Tipe Publikasi & Proceeding & 1 & 0,159 & 0,505 & 0,614 & \multirow{4}{*}{7,845} & \multirow{4}{*}{3} & \multirow{4}{*}{0,049} \\
\hline & & Jurnal & 7 & 1,541 & 3,742 & 0,000 & & & \\
\hline & & Skripsi & 3 & 0,848 & 5,667 & 0,000 & & & \\
\hline & & Tesis & 1 & 0,963 & 3,902 & 0,000 & & & \\
\hline
\end{tabular}

Pertama, pada Tabel 7 ada dua tahun publikasi yang memiliki ukuran efek lebih tinggi yaitu pada tahun 2017 dan 2020 dalam penerapan model PjBL pada proses pembelajaran. Hal ini berbeda dengan penelitian yang dilakukan oleh (Kadir, 2017) bahwa penerapan intervensi pembelajaran (model PjBL salah satunya) memiliki ukuran terbesar terhadap kemampuan matematis pada tahun penelitian 2018 . Berdasarkan Tabel 7. $Q b=6,663<$ Qtabel $=$ 11,070 dan $p>0,05$. Berarti tidak terdapat perbedaan yang signifikan pada implementasi model PjBL terhadap kemampuan berpikir kreatif jika ditinjau dari tahun publikasi. 
DOI: https://doi.org/10.24127/ajpm.v10i3.3705

Kedua, Karakteristik studi yang ditinjau dari sumber publikasi menujukan bahwa hasil penelitian yang memiliki ukuran efek yang lebih besar terdapat pada tipe publikasi artikel pada jurnal dan tesis. Hal ini sejalan dengan penelitian lain yang meneliti pengaruh model pembelajaran kontruktivis memiliki ukuran efek tertinggi pada tipe publikasi artikel (Arik \& Yilmaz, 2020) dan dibidang lain seperti sains pun model PjBL memiliki ukuran efek lebih besar pada publikasi tesis (Anggreni et al., 2019). Apabila ditinjau dari tingkat heterogenitas, nila $\mathrm{Qb}=7,845>\mathrm{Q}$ tabel $=$ 5,991 dan $\mathrm{p}<0.05$ menjunjukkan bahwa terdapat perbedaan secara signifikan apabila ditinjau dari tipe publikasi pada pengaruh model PjBL terhadap kemampuan berpikir kreatif matematis siswa. Meskipun demikian perbedaan tersebut tidak mengindikasikan bias publikasi sebab ukuran efek rata-rata dari publikasi artikel lebih tinggi dari kategori lainnya.

\section{KESIMPULAN DAN SARAN}

Pada penelitian ini terdapat dua belas studi yang dianalisis. Penilaian kualitas dari dua belas studi sebesar 0,75 (sedang) dengan tingkat reliabel 61\%. Efektivitas model PjBL lebih tinggi secara signifikan terhadap kemampuan berpikir kreatif dengan menggunakan model efek acak sebesar 1,190 dengan tingkat kepercayaan 95\%. Pada penelitian lanjutan berupa analisis karakteristik studi yang ditinjau pada aspek subtantif dan ektrinsik. Pada aspek subtantif, bahwa para pendidik dan pemangku kebijakan dapat menerapkan model PjBL memiliki efektif lebih tinggi terhadap kemampuan berpikir kreatif matematis siswa apabila diterapkan pada jenjang pendidikan sekolah menengah, memiliki ukuran sampel berjumlah $\geq 31$ siswa, teknik pengambilan sampel yang tepat lebih baik menggunakan sistem random. Sedangkan analisis pada aspek ektrinsik berupa tahun publikasi yang paling berpengaruh terjadi pada tahun 2017 dan 2020, dan tipe publikasi yang tepat dipilih menggunakan tipe publikasi artikel pada jurnal.

Dari penelitian ini, ada beberapa rekomendasi untuk dilakukan penelitian berikutnya dimasa yang akan datang. Waktu terus berjalan, tentu akan banyak bermunculan penelitian dari penulis baru mengenai pengaruh model $\mathrm{PjBL}$ terhadap kemampuan berpikir kreatif matematis siswa, begitupun dapat meningkatkan jumlah studi yang dianalisis dari studi meta-analisis sebelumnya. Semakin banyak studi yang dianalisis maka gambar plot corong akan terlihat jelas tingkat simetris dari kumpulan ukuran efek studi yang dianalisis dan kecendrungan bebas akan bias publikasi pun akan tinggi pula. Selain itu ada beberapa kelompok aspek pada karakteristik studi yang belum dianalisis meliputi aspek subtantif meliputi kelas dan durasi perlakuan sedangkan pada aspek ektrinsik meliputi index publikasi dan area studi. Rekomendasi ini diharapkan mampu menambah kajian literatur dan memperoleh informasi secara mendalam dan lengkap untuk dimanfaatkan oleh guru matematika dan pemangku kebijakan.

\section{DAFTAR PUSTAKA}

Anggreni, Y. D., Festiyed, \& Asrizal. (2019). Meta-analisis Pengaruh Model Pembelajaran Project Based Learning Terhadap Kemampuan Berpikir Kritis Peserta Didik SMA. Pillar of Physics Education, 12(4), 881-888. https://doi.org/10.24036/79121710 74 
Arik, S., \& Yilmaz, M. (2020). The effect of constructivist learning approach and active learning on environmental education: A metaanalysis study. International Electronic Journal of Environmental Education, 10(1), 44-84.

https://files.eric.ed.gov/fulltext/EJ1 239355.pdf

Balemen, N., \& Ozer Keskin, M. (2018). The Effectiveness of Project-Based Learning on Science Education: a Meta-Analysis Search. International Online Journal of Education and Teaching (Iojet), 5(4), 849-865.

Borenstein, M., Hedges, L. V, \& Rothstein, H. R. (2009). Introduction Meta-Analysis (Issue January). John Wiley \& Sons.

Cohen, L., Manion, L., \& Morrison, K. (2018). Research Methods in Education (8th ed.). Routledge Taylor \& Francis Group.

Damayanti, H. T., \& Sumardi. (2018). Mathematical Creative Thinking Ability of Junior High School Students in Solving Open-Ended Problem. Journal of Research and Advances in Mathematics Education, 3(1), 36-45. https://doi.org/10.1088/17426596/1806/1/012069

De Raadt, A., Warrens, M. J., Bosker, R. J., \& Kiers, H. A. L. (2019). Kappa Coefficients for Missing Data. Educational and Psychological Measurement, 79(3), 558-576. https://doi.org/10.1177/001316441 8823249

Fadhli, M., Brick, B., Setyosari, P., Ulfa, S., \& Kuswandi, D. (2020). A Meta-Analysis of Selected Studies on the Effectiveness of Gamification Method for Children.
International
Journal of Instruction, 13(1), 845-854. https://doi.org/10.29333/iji.2020.1 $3154 \mathrm{a}$

Fournier, K. A., Hass, C. J., Naik, S. K., Lodha, N., \& Cauraugh, J. H. (2010). Motor coordination in autism spectrum disorders: A synthesis and meta-analysis. Journal of Autism and Developmental Disorders, 40(10), 1227-1240.

https://doi.org/10.1007/s10803010-0981-3

Girgin, D. (2020). Evaluation of Project-Based Learning Process of Gifted Children via Reflective Journals. International Journal of Curriculum and Instryction, 12(2), 772-796.

Hidayah, I., Isnarto, Masrukan, Asikin, M., \& Margunani. (2020). Quality Management of Mathematics Manipulative Products to Support Students' Higher Order Thinking Skills. International Journal of Instruction, 14(1), 537-554. https://doi.org/10.29333/IJI.2021.1 4132A

Jackson, D., \& Turner, R. (2017). Power Analysis for RandomEffects Meta-analysis. Research Synthesis Methods, 8(3), 290-302. https://doi.org/10.1002/jrsm.1240

Jalinus, N., Syahril, Nabawi, R. A., \& Arbi, Y. (2020). How ProjectBased Learning and Direct Teaching Models Affect Teamwork and Welding Skills Among Students. International Journal of Innovation, Creativity and Change, 11(11), 85-111.

Juandi, D., Kusumah, Y. S., Tamur, M., Perbowo, K. S., Siagian, M. D., Sulastri, R., \& Negara, H. R. P. (2021). The Effectiveness of Dynamic Geometry Software 
DOI: https://doi.org/10.24127/ajpm.v10i3.3705

Applications in Learning Mathematics: A Meta- Analysis Study. International Journal Interactive Mobile Technologies, 15(02), 18-37. https://doi.org/10.3991/ijim.v15i02 .18853

Juandi, D., Kusumah, Y. S., Tamur, M., Perbowo, K. S., \& Wijaya, T. T. (2021). A meta-analysis of Geogebra software decade of assisted mathematics learning: what to learn and where to go? Heliyon, 7(5), e06953. https://doi.org/10.1016/j.heliyon.20 21.e06953

Juandi, D., \& Tamur, M. (2020). Pengantar Analisis Meta (1st ed.). UPI PRESS.

Juandi, D., \& Tamur, M. (2021). The impact of problem-based learning toward enhancing mathematical thinking: A meta-analysis study. Journal of Engineering Science and Technology, 16(4), 35483561.

Kadir, K. (2017). Meta-Analysis of the Effect of Learning Intervention Toward Mathematical Thinking on Research and Publication of Student. TARBIYA: Journal of Education in Muslim Society, 4(2), 162-175.

https://doi.org/10.15408/tjems.v4i2 .8010

Kot, M., Terzioglu, N. K., Aktas, B., \& Yikmis, A. (2018). Effectiveness of Touch Math Technique: MetaAnalysis Study. Online Submission, 3(4), 100-111. https://doi.org/10.5281/zenodo.132 6894

Lee, Y. H. (2019). Strengths and Limitations of Meta-Analysis. The Korean Journal of Medicine, 94(5), 391-395. https://doi.org/10.3904/kjm.2019.9
4.5.391

Maeda, Y., \& Harwell, M. (2016). Guidelines for Using the "Q" Test in Meta-Analysis. Mid-Western Educational Researcher, 28(1), 55-72.

Moeyaert, M. (2019). Quantitative Synthesis of Research Evidence: Multilevel Meta-Analysis. Behavioral Disorders, 44(4), 241256.

https://doi.org/10.1177/019874291 8806926

Mullen, B., Muellerleile, P., \& Bryant, B. (2001). Cumulative metaanalysis: A consideration of indicators of sufficiency and stability. Personality and Social Psychology Bulletin, 27(11), 14501462.

https://doi.org/10.1177/014616720 12711006

Ngiamsunthorn, P. S. (2020). Promoting Creative Thinking for Gifted Students in Undergraduate Mathematics. JRAMathEdu (Journal of Research and Advances in Mathematics Education), 5(1), 13-25. https://doi.org/10.23917/jramathed u.v5i1.9675

Noviyana, H. (2017). Pengaruh Model Project Based Learning Terhadap Kemampuan Berpikir Kreatif Matematika Siswa. Jurnal Edumath, 3(2), 110-117.

Nurhayati, S. (2017). Model Pembelajaran Project Based Learning Ditinjau dari Keterampilan Berpikir Kreatif pada Materi Statistika Siswa Kelas VII SMPN 1 Ngronggot. SimkiTechsin, 01(7), 1-7.

Octariani, D., \& Rambe, I. H. (2020). Model Pembelajaran Berbasis Project Based Learning Untuk Meningkatkan Kemampuan 
DOI: https://doi.org/10.24127/ajpm.v10i3.3705

Berpikir Kreatif Matematika Siswa SMA. Genta Mulia, XI(1), 126130.

Oh-Young, C., Filler, J., \& Buchter, J. (2020). The Meta-Analysis Review: A Valuable Resource for Special Educators. Intervention in School and Clinic, 55(3), 139-144. https://doi.org/10.1177/105345121 9842222

Paloloang, M. F. B., Juandi, D., Tamur, M., Paloloang, B., \& Adem, A. M. G. (2020). Meta Analisis: Pengaruh Problem-Based Learning Terhadap Kemampuan Literasi Matematis Siswa Di Indonesia Tujuh Tahun Terakhir. AKSIOMA: Jurnal Program Studi Pendidikan Matematika, 9(4), 851-864. https://doi.org/10.24127/ajpm.v9i4. 3049

Sari, Y. K., Juandi, D., Tamur, M., \& Adem, A. M. G. (2021). MetaAnalysis: Mengevaluasi Efektivitas Problem Based Learning pada Kemampuan Pemahaman Matematis Siswa. Journal of Honai Math, 4(1), 1-18. https://doi.org/10.30862/jhm.v4i1. 144

Shalihah, N. H., Dafik, \& Prastiti, T. D. (2020). The Analysis of The Application of Learning Materials Based on Project-Based Learning to Improve The Elementary School Students' Creative Thinking Skills in Solving Contextual Division Problems. Journal of Physics: Conference Series, 1563, 1-17. https://doi.org/10.1088/17426596/1563/1/012044

Siegel, L., Murad, M. H., \& Chu, H. (2021). Estimating The Reference Range From a Meta-analysis. Research Synthesis Methods, 12(2), 148-160. https://doi.org/10.1002/jrsm.1442 Sudianto, S., Dwijanto, \& Dewi, N. R. (2019). Students' Creative Thinking Abilities and Self Regulated Learning on ProjectBased Learning with LMS Moodle. Unnes Journal of Mathematics Education Research, 8(1), 10-17.

Suparman, Juandi, D., \& Tamur, M. (2021a). Problem-Based Learning for Mathematical Critical Thinking Skills: A Meta-Analysis. Journal of Hunan University (Natural Sciences) , 48(2), 133-144.

Suparman, Juandi, D., \& Tamur, M. (2021b). Does Problem-Based Learning Enhance Students , Higher Order Thinking Skills in Mathematics Learning? A Systematic Review and MetaAnalysis. 2021 4th Inter-National Conference on Big Data and Education (ICBDE'21), 44-51. https://doi.org/10.1145/3451400.34 51408

Suparman, S., Juandi, D., \& Tamur, M. (2021c). Review of problem-based learning trends in 2010-2020: A meta-analysis study of the effect of problem-based learning in enhancing mathematical problemsolving skills of Indonesian students. Journal of Physics: Conference Series, 1722(1), 012103.

https://doi.org/10.1088/17426596/1722/1/012103

Suparman, Tamur, M., Yunita, Wijaya, T. T., \& Syaharuddin. (2021). Using Problem-Based Learning to Enhance Mathematical Abilities of Primary School Students: A Systematic Review and MetaAnalysis. Jurnal Teori Dan Aplikasi Matematika, 5(1), 144161. 
DOI: https://doi.org/10.24127/ajpm.v10i3.3705

https://doi.org/10.31764/jtam.v5i1. 3806

Susanti, N., Juandi, D., \& Tamur, M. (2020). The Effect of ProblemBased Learning ( PBL ) Model On Mathematical Communication Skills of Junior High School Students - A Meta-Analysis Study. JTAM (Jurnal Teori Dan Aplikasi Matematika), 4(2), 145-154. https://doi.org/10.31764/jtam.v4i2. 2481

Syahrin, A., Dawud, Suwignyo, H., \& Priyatni, E. T. (2019). Creative Thinking Patterns in Student's Scientific Works. Eurasian Journal of Educationa; Research, 81, 21-36. https://doi.org/10.14689/ejer.2019. 81.2

Tamur, M, Fedi, S., Sennen, E., Marzuki, Nurjaman, A., \& Ndiung, S. (2021). A meta-analysis of the last decade STEM implementation: what to learn and where to go. Journal of Physics: Conference Series, 1882(1), 012082.

https://doi.org/10.1088/17426596/1882/1/012082

Tamur, M, Jehadus, E., Nendi, F., Mandur, K., \& Murni, V. (2020). Assessing the effectiveness of the contextual teaching and learning model on students 'mathematical understanding ability: a metaanalysis study. Journal of Physics: Conference Series, 1657(1), 012067.

https://doi.org/10.1088/17426596/1657/1/012067

Tamur, M, \& Juandi, D. (2020). Effectiveness of Constructivism Based Learning Models Against Students Mathematical Creative Thinking Abilities in Indonesia: A Meta-Analysis Study. Pervasive
Health: Pervasive Computing Technologies for Healthcare, 1, 107-114.

https://doi.org/10.4108/eai.12-102019.2296507

Tamur, Maximus, \& Juandi, D. (2020). Effectiveness of Constructivism Based Learning Models Against Students Mathematical Creative Thinking Abilities in Indonesia: A Meta-Analysis Study. Mathematics, Science, and Computer Science Education International Seminar, MSCEIS 2019, 1-8. https://doi.org/10.4108/eai.12-102019.2296507

Tamur, Maximus, Juandi, D., \& Adem, A. M. G. (2020). Realistic Mathematics Education in Indonesia and Recommendations for Future Implementation: A Meta-Analysis Study. Jurnal Teori Dan Aplikasi Matematika, 4(1), 17-27.

https://doi.org/10.31764/jtam.v4i1. 1786

Tamur, Maximus, Juandi, D., \& Kusumah, Y. S. (2020). The Effectiveness of the Application of Mathematical Software in Indonesia: A Meta-Analysis Study. International Journal of Instruction, 13(4), 867-884. https://doi.org/10.29333/iji.2020.1 3453a

Tamur, Maximus, Kurnila, V. S., Jehadus, E., Ndiung, S., Pareira, J., \& Syaharuddin, S. (2021). Learning from the Past: MetaAnalysis of Contextual TeachingLearning of the Past Decade. International Journal of Education \& Curriculum Application, 4(1), $1-10$.

https://doi.org/10.31764/ijeca.v4i1. 3981 
DOI: https://doi.org/10.24127/ajpm.v10i3.3705

Tamur, Maximus, Ndiung, S., Nurjaman, A., \& Pereira, J. (2021). Do differences in measured mathematical abilities moderate the effectiveness of the realistic mathematics education approach? Meta-analysis studies. Jurnal Math Educator Nusantara, 7(1), 12-25. https://doi.org/10.29407/jmen.v7i1. 15736

Ummah, S. K., Inam, A., \& Azmi, R. D. (2019). Creating Manipulative: Improving Students' Creativity Through Project-Based Learning. Journal on Mathematics Education, 10(1), 93-102. https://doi.org/10.22342/jme.10.1.5 093.93-102

Yunita, Y., Juandi, D., Tamur, M., Adem, A. M. G., \& Pereira, J. (2020). A meta-analysis of the effects of problem-based learning on students ' creative thinking in mathematics. Beta: Jurnal Tadris Matematika, 13(2), 104-116. https://doi.org/10.20414/betajtm.v1 $3 \mathrm{i} 2.380$

Yunita, Y., Wahidin, W., \& Tsurayya, A. (2018). The Development of Mathematics Higher Order Thinking Skills Instrument for Grade VIII junior High School. Journal of Physics: Conference Series, 1088, 1-6. https://doi.org/10.1088/17426596/1088/1/012093 